\title{
ON
}

\section{HY PERTROPHY}

\author{
AND

\section{ATROPHY OF THE BRAIN,} \\ By JOHN SIMS, M.D., \\ PHYSICIAN TO THE ST. MARY-LE-BONE INFIRMARY.
}

READ MAY 26TH, AND JUNE 9TH, 1835.

I.

Hypertrophy.

THE term hypertrophy of the brain has been restricted by some pathologists to an unnatural increase of volume of the organ, by the mere addition of particles of the same character as the original : this definition implies a too limited view of the subject. In the following pages I shall use the term as referable to two states; one consisting in simple enlargement, the other where a change of texture in the cerebral substance also exists.

In the writings of pathologists, allusions have sometimes been made to the circumstance of the brain far exceeding the ordinary or average magnitude; we are however chiefly indebted to the French pathologists of the present century, for calling our attention to the subject of hypertrophy as one of the dis- 
eases of the brain. British physicians have very rarely taken any notice of it.

I intend, in the first place, to give a very short report of the opinions of a few authors who have written on the subject.

II. To relate the histories of several cases of hypertrophy which have fallen under my observation.

III. To attempt to ascertain the average weight of the brain of persons of all ages, from a very large number of cases in which the brain has been weighed.

IV. To give short notices of a number of brains which exceeded the average weight, from various causes, but which scarcely come under the description of hypertrophy.

V. To relate the histories 'of several cases of atrophy of the brain, both general and partial.

VI. In conclusion, to draw such inferences as the facts and observations, detailed in the paper, appear to warrant.

In the Journal de Médecine, \&c., edited by Corvisart, Leroux, and Boyer, for June, 1806, there is a paper on hydrocephalus internus, by M. Matthey, of Geneva, to which is appended another, entitled, "Reflexions sur les observations précédentes et sur 
l'hydrocéphale aiguë en general", by M. Laennec. This distinguished pathologist appears to be one of the earliest in France to notice hypertrophy of the brain. After alluding to the observation of Morgagni, that in some bodies which he had examined, the brain seemed to be too large for the cranium which enclosed it, and on this account appeared to be compressed, he remarks, “ $M$. Jadelot m'a dit avoir observé la même chose chez les enfans, et avoir remarqué q'un grand nombre de ceux qui meurent avec les symptomes de l'hydrocéphale interne, n'offrent autre chose à l'ouverture du cadavre que cette disproportion de volume entre le cerveau et le crâne. Il m'est aussi arrivé de voir quelques sujets que j’avais regardé comme attaqués d'hydrocéphale interne, et qui à l'ouverture des cadavres, n'ont présenté qu'une très petite quantité d'eau dans les ventricules, tandis que les circonvolutions du cerveau, fortement applaties, annonçaient que ce viscère avait subi une compression qui ne pouvait être attribuée qu'à un volume trop grand et par conséquent à une nutrition trop active de la masse cérébrale." *

The observations of Laennec appear to refer exclusively to hypertrophy of the brain in children, and to those cases in which signs of hydrocephalus internus had been observed during life. He is also not aware of any change in the appearance or texture

* Journal de Médecine, by Corvisart, \&c. Tome II. p. 669. 
of the cerebral substance, except mere augmentation of volume *.

In the seventh volume of the Archives Générales de Médecine, M. Scoutetten relates a case of hypertrophy in the brain of a boy æt. $5 \frac{1}{2}$ years, in whom there was nothing remarkable, except the size and weight of his head, until within sixteen days of his death, when febrile symptoms came on, attended with more marked head symptoms during the last day or two. On examining the head, the brain was found to be much larger, and to have acquired a greater degree of consistence in all its parts than is usual in a child of five years old. The superior and posterior parts of the hemispheres were found to be those principally enlarged $\dagger$.

M. Dance published, in 1828, a paper in the Repertoire Général d' Anatomie et de Physiologie, \&c., entitled "Observations pour servir à l'histoire de l'hypertrophie du cerveau." This essay has been generally referred to by subsequent writers as the best on this subject; it is however a very slender and imperfect description of this state of the brain. The

* “ L'augmentation de volume du cerveau n'entraînant aucune alteration dans la texture de ce viscère, il ne serait nullement étonnant qu'on n’y eût fait aucune attention." Op. Cit. p. 671. + " Le cerveau, devenu tres volumineux présénte dans toutes ses parties plus de consistance qu'il n'en a ordinairement chez un enfant de cinq ans."-Archives Générales de Médecine, Tom. VII., p. 44. 
author confines the term hypertrophy to an unnatural increase or accumulation, either in number or size, of the constituent atoms proper to any organ, and excludes the increase of volume which results from inflammation of the brain, serous or sanguineous congestion in its substance, or effusion into its cavities*. He relates four cases of this affection. In the first, the patient received a blow on the head about seven months before his death; he afterwards suffered epistaxis, severe and frequent paroxysms of head-ache. He fell down in walking from the bath, and died convulsed in about a quarter of an hour. On inspecting the brain, the convolutions were flattened; there was very little blood and no serous fluid in the encephalon. The author thus describes the appearance of the substance of the brain. "Toute la substance cérébrale resemblait à du blanc d'œuf durci par la coction, son poids et sa densité etaient considerables, elle ne s'affaisent point et resistait sous la pression. Soumise à une traction modérée, elle s'allongeait sans se rompre, et revenait ensuite sur elle-même, à la manière d'un corps elastique ; on n'y

* "Par ce mot d'hypertrophie, nous ne voulons pas désigner l'augmentation de volume qui est le résultat d'une inflammation du cerveau, d'une congestion sanguine ou sereuse dans sa substance, ou d'un épanchement dans ses cavités; l'afflux et la stase des liquides augmentent alors en effet la masse apparente de ce viscère, mais ces liquides ne sont point incorporeés et identifiés avec sa substance, comme il arrive dans l'hypertrophie véritable, qui consiste essentiellement dans l'accroissement contre nature, soit en nombre, soit en volume, des molecules constituantes propre à chaque organe." 
appercevait aucune trace de vaisseaux, aucune ponctuation ou coloration rouge; tout au contraire la substance corticale paraissait plus pâle, et la substance médullaire plus blanche que dans l'etat naturel."* The second and third cases present appearances somewhat similar to the first: the fourth case is misplaced, as it scarcely comes within the description of hypertrophy. In three of the cases where the cerebellum is mentioned, it is observed to be natural.

Portal, in his Treatise on Epilepsy, relates a case which comes strictly within the description of hypertrophy of the brain $t$.

Otto, in his Compendium of Pathological Anatomy, by South, remarks that hypertrophy of the brain is especially produced in rickets, and in rare cases may occur even before birth; that it frequently occurs at

* Répertoire General d'Anatomie et de Physiologie Pathologique, \&c. Tome V. p. 197. I have not been able to meet with the Number of the Revue Médicale, containing the Essay of

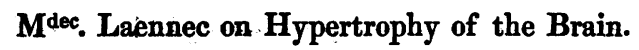

+ “Un chaudronnier agé d'environ 30 ans. L'ouverture du corps fut fait par M. Le Dac, qui reconnut que le cerveau etait engorgé de sang, et que cet organe etait d'un tel volume que la culotte du crâne ayant été enlévée, le cerveau parait faire plus de saillié qu'a l'ordinaire, aussi eut on beaucoup de peine à le recouvrir par cette même culotte.

“ La substance du cerveau cependant au lieu d'étre ramollie, etait en general durcie, principalement le corps calleux et autres parties de la substance medullaire, quoique paraissant plus imbibée de serosités que dans l'etat naturelle, les plexus choroides etaient gorgés d'un sang noir." Sur l'Epilepsie, page 8. 
birth, and sometimes attains a very large size : he supposes also that hypertrophy may be a mode of cure in a brain, the ventricles of which have been expanded by fluid at some former period. The cases of hypertrophy of particular parts of the brain he thinks are usually connected with vice of texture. In allusion to the state of brain which may be called acute hypertrophy, he remarks, "I have twice seen this to such extent that the elasticity of the brain thrust up the solid calvaria at certain points by bursting asunder slight fractures: the one case occurred in an epileptic patient; the other in a body brought into the anatomical theatre, of which I have no account." *

Andral, in the last volume of his "Clinique Medicale," has an interesting chapter on hypertrophy of the brain. He supposes that the frequent repetition of cerebral hyperemia may be, amongst others, a cause of hypertrophy. He suggests the question, whether the hypertrophy we often find as the sole lesion in epilepsy may not be the cause of the disease, or whether it may be the effect of the frequent returns of the epileptic paroxysm. He relates four cases in which the appearances in the texture of the brain generally correspond, and are described almost in the words of Dance $\uparrow$.

* Compend. of Pathological Anatomy, by South, p. 390, et seq.

$\uparrow$ Clinique Medicale, Tome V., p. 595.

In the Précis d'Anatomie Pathologique, Andral gives the folvor. XIX. 
Hypertrophy of the brain has been but little noticed by British pathologists; some allusions have, however, been recently made to the subject.

Dr. Bright, in his work on " Diseases of the Brain," relates óne example of this disease, (Case 171,) which is referred to in the "Concise statement of the morbid appearances," under the head of "Increased volume of the brain ;" and in the paragraph "Convolutions flattened," he observes, "the convolutions are occasionally found to be compressed without our being able to discover any obvious cause except a disproportion between the volume of the brain and the cavity of the skull." He refers to cases 308 and 259 : the first presents all the signs of hypertrophy in a child, who received an injury of the head three weeks before death and suffered repeated convulsion fits : the other case seems more properly referable to the encroachment of a morbid growth within the skull, producing the flattening of the convolutions, as noticed

lowing definition of hypertrophy : - “ L'hypertrophie du cerveau présente les caractères anatomiques suivans : les circonvolutions sont rapprochées et applaties; on ne voit plus aucun intervalle entr'elles; il semble que les meninges, immédiatement appliquées sur le cerveau, soient devenues trop étroites pour le contenir. La substance nerveuse est ferme, et oppose à la traction une resistance inaccoutumée; elle contient peu de sang, et lorsqu'on l'incise, on est frappé de la sécheresse des coupes. Les ventricules sont comme effacés, et les surfaces encephaliques sont privées de leur humidité ordinaire. Du reste, la texture du cerveau n'a subie aucune alteration." Tome II., p. 775. 
in the succeeding part of the paragraph from whence I have quoted *.

Dr. Alexander Thomson has recorded a case of "Hypertrophy of the Cerebrum, accompanied by ramollissement, mistaken for chronic hydrocephalus," in the Lancet for July, 1830. I shall have occasion to notice this case in reference to one analogous to it in a subsequent part of this paper $\downarrow$.

In the numerous dissections of the brain in fever reported by Dr. Smith, he mentions one instance in which " the substance of the brain was exceedingly firm, and seemed to distend and protrude its membranes, so that there seemed something like hypertrophy of its substance." $\ddagger$

In a lecture by Dr. Elliotson, printed in the Medical Gazette for 1832, he incidentally alludes to hypertrophy of the brain. The lecture appears to be elementary, and the author remarks, "I never saw but one instance of this affection :..... the brain had become larger than it should be; it caused the skull to be very much beyond the usual dimensions, and looked, on opening the skull, as if it had been ready to burst asunder. The convolutions were all very large." The patient was a boy, who was ex675.

* Medical Reports, “Diseases of the Brain." Part II. p.

+ Lancet, No. CCCLXI, (Supplement) 1830, p. 699.

$\ddagger$ Treatise on Fever, by Dr. Southwood Smith. 
ceedingly precocious ; had a head larger than a man's; his character corresponded with that of an adult: he suddenly became apoplectic, hemiplegic, and died. Nothing was found on dissection but an excessive size of the organ, the brain in other respects being healthy*.

Mr. Sweatman has related a case of " premature development of the brain," in a child two years old; the cerebellum partaking of the enlargement, though in a less degree than the cerebrum. The head measured from ear to ear, over the vertex, twelve inches; the circumference, twenty-one inches; the weight of the brain, two pounds fifteen ounces and a half, avoirdupois. In this case the brain was highly vascular, and the convolutions had their usual rounded appearancet.

In a paper by Dr. Stoker, on " apoplexia cephalitica," the author proposes to divide Cullen's third species into two varieties, viz. apoplexia cephalitica and apoplexia hydrocephalica, in order to include in the former those cases where the symptoms have clearly marked the disease termed hydrocephalus acutus, but in which on dissection no fluid was found in the encephalon. The principal case which he adduces as the ground of his views, appears, from the following short account given of the dissection, to be one of hyper-

* Medical Gazette, Vol. IX., p. 622.

+ Med. Gaz., Vol. XV., p. 504. 
trophy of the brain. A young gentleman, æt. 11, was attended by Dr. Grattan and the author: he suffered fever of twenty-one days' duration, and in the last eight days acute headache, delirium, tossing the hands to the head, strabismus, dilatation of the pupils, and impaired vision supervened. The following is the report of the dissection of the brain:" On the most minute examination of the brain, made by Mr. Kirby the day after death, no effusion or disorganization could be detected in it, excepting that when the cranium was first removed the encephalon seemed to us to be in size more than proportioned to the bone that contained it, and to expand itself considerably over the under section of the base of the cranium."*

In the article "Hypertrophy" (Brain) in the Cyclopedia of Practical Medicine, by Dr. Townsend, a very brief description is given, taken from some of the writers on the subject. Vol. I.

Having given a short survey of the principal part of what has been recorded more recently on the subject of hypertrophy of the brain, I shall now proceed to relate several cases of this affection which have fallen under my notice; and in doing so, I must bespeak the patience, or at least the indulgence of the Society, for I am well aware that I have little more to produce than a dry detail of facts and observations.

* 'Trans. of Dublin College Association, Vol. II., p. 34. 
The subject is however, I conceive, in all its bearings, well worthy the attention of the pathologist and the physician.

\section{CASE I.}

Hypertrophy of the Brain; death from Enteritis.

I was requested by one of my friends to accompany him to examine the body of A. B., æt. 16, who had died from inflammation of the bowels. After the examination of the cavity of the abdomen was completed, her head being now uncovered, I remarked to her mother that there must be some disease in the brain, from the enormous size of her daughter's head. She observed, " $\mathrm{Oh}$, Sir, that is an old complaint; ever since she was a child she has had water in the head. She has been a patient of one of the hospitals, and they wished to tap her head, but I would not consent to it." I returned in the evening, and examined the head. From her mother I learned the following particulars of her history. She was subject to some kind of fits until she was seven years old : the catamenia appeared at fourteen; she had an enormous appetite ; there was no paralysis, but a very great weakness of all her limbs ; she complained much of giddiness, and had a bad memory; she had a difficulty in learning and performing the ordinary mechanical arts of her sex, as sewing, \&c.

The attack of enteritis came on from exposure to wet, and speedily proved fatal. No cerebral sym- 
ptoms were noticed by her medical attendant during her last illness.

Inspection of the body.-The head appeared to be nearly twice the ordinary size for a girl of her age, with a remarkably large and perpendicular forehead; her features were handsome; her expanded forehead resembled that of some of the finest busts of Jupiter. She was broad across the pelvis ; her extremities rather less than usual, and her hands remarkably small.

Head.-Ossification of the cranium complete. Brain: the arachnoid was much thickened by the deposition of slightly opaque lymph on the upper parts of both hemispheres. The cerebrum was very firm to the knife, and presented no unusual appearance except its enormous size: the quantity of brain appeared to be double that of a person of her age. The cerebellum did not partake of the enlargement. The ventricles contained only from two to three ounces of clear fluid. The cranium was not measured, nor the brain weighed.

Abdomen.-The descending portion of the colon was perforated by ulceration. The peritoneum was highly inflamed, and in the left iliac region there were considerable adhesions by plastic lymph between the parietes of the abdomen and the contiguous portions of the alimentary canal.

Remarks.-This appears to be a case allied to 
rickets, from the imperfect development of some parts of the body. The brain was simply enlarged: the texture of it did not present any thing in its consistence or in any other respects different from ordinary cerebral substance. The disposition to enlargement of the brain, if it did not commence before birth, most probably appeared at a very early age, for the size of the girl's head very soon attracted the attention of her mother and the medical men whom she consulted. The preceding " fits," loss of memory, small hands, and defective power of using them, are all circumstances of considerable interest in this case. She had no brain symptoms during her last illness, and the increased development of the brain does not appear to have been incompatible with the continuance of life, her death being occasioned by a disease entirely independent of it,-a perforation of the intestine in consequence of inflammation.

\section{CA SE II.}

Hypertrophy of the Brain. Death from Extravasation of Blood into one of the Crura Cerebri. Disease of the Stomach and Duodenum.

Martha Lock, æt. 40, has been in the Infirmary upwards of three years, and from the great severity of her sufferings had particularly, and for a long time, attracted the attention of some of the Directors and others who occasionally visited the hospital. She fell 
to my lot on the division of the patients when Dr. Hooper retired, and remained under my care until the time of her death.

She has for several years suffered at intervals severe paroxysms of pain referable to the pyloric end of the stomach and duodenum, accompanied with vomiting of large quantities of thin mucous and green bilious fluid, amounting to many pints during the paroxysm. The paroxysm is also attended with the most intense head-ache. Her sufferings have been sometimes so great as to deprive her of reason for a time, and at others to produce a state of coma. In one of the attacks she bit her tongue nearly half across, and more than once attempted to destroy herself in order to put an end to her agony.

June 8, 1832. For the last three days she has been suffering a paroxysm of very great severity, attended with violent convulsive agitation, and vomiting of dark green fluids, with constant purging. She had two fits of an epileptic character yesterday, and three this morning. She died suddenly about one, p. $\mathrm{m}$.

Inspection 24 hours after death.-Head, A considerable quantity of blood escaped on dividing the skull. On removing the calvaria the dura mater was remarkably distended, and appeared protruding as from pressure within. The convolutions 
were much flattened, and their divisions almost obliterated. The medullary matter was throughout of a dead or flake white colour; scarcely any red points appearing in the sections made of the bloodvessels ramifying through it. The substance of the brain appeared to be much increased in firmness and in bulk. The membranes were very dry, and the pia mater adhered very firmly to the surface of the brain. The ventricles were contracted in size, and contained no fluid. In the right crus cerebri, which was in some slight degree softened, there was a small clot of recently extravasated blood, the size of a pea. A small body, very much resembling an enlarged absorbent gland in any other part of the body, was found in the arachnoid near the basilar artery. Cerebellum natural. The brain was not weighed.

Thorax.-Heart : hypertrophy of the left ventricle, with contraction of the cavity. In the lungs, a small cavity in the upper part of one of the lobes.

Abdomen. Stomach.-The mucous membrane was much thickened and vascular, and this thickening extended to the tissue beneath. The rugæ were large and elevated : a considerable quantity of mucus adhered to the surface. The pyloric valve was much thickened, and its area contracted.

Intestines.-The duodenum was considerably di- 
lated; there was high vascularity of the mucous membrane, and thickening throughout: this vascularity extended to some distance along the small intestine.

Pancreas.-The blood-vessels remarkably large and dilated. Liver and kidneys healthy. Spleen small and broken down. Uterus healthy. Small cysts in the ovaries *.

Remarks.-In this case the hypertrophy of the brain was probably influenced, if not occasioned by the diseased state of the stomach and duodenum, producing the frequent paroxysms of continued vomiting and severe headache; and I think it is highly probable that, in the more severe forms of what is commonly termed sick headache, a state of the brain may be induced by its frequent recurrence, favourable to, or ultimately productive of, hypertrophy of this organ.

The fatal termination of this case took place almost instantaneously from the small quantity of blood extravasated in the right crus cerebri. The

* In the "Principles and Illustrations of Morbid Anatomy," published by Dr. Hope, he has incidentally alluded to the morbid appearance of the stomach of this patient, but he has been led into a mistake in stating that "the other viscera were healthy." Probably he might not have been present when thesè organs were examined. "Description of Plates," p. lxvi. 
pons varolii and the crura are highly impatient of injury, and probably the part affected in the brain had some share in producing the speedy death; but it would also appear that, on the principle of compression, the brain, already expanded beyond its due bounds, could not sustain the increased pressure of a very small quantity of extravasated blood.

In reference to sanguineous apoplexy and other diseases of the brain, $I$ believe the future investigation of the subject of this paper will lead to important pathological and practical results.

In an instance of a man 50 years of age, who died suddenly from rupture of one of the aortic valves, and who had complained of constant nausea, vomiting of food, pains in the pit of the stomach, and other signs of organic disease of the stomach, on inspecting the body the pylorus was diseased, and the brain was found to be very large and pale, and weighing 3 lbs. 1 oz. with very small ventricles: the arachnoid membrane was opaque, and some fluid was contained beneath it.

The first case reported by M. Dance resembles this in the suddenness of the death of the patient, most probably arising from simple sanguineous apoplexy. The second case of the same author also resembles it, in the convulsions preceded by copious green vomiting. 


\section{A SE III.}

Hypertrophy of the Brain; Convulsions;

Insensibility; Stertorous Breathing.

Joseph Trendal, æt. 22. A short time ago he had taken a large quantity of mercury for the cure of syphilis. He was admitted March 6th, 1833. He was reported insane, but when visited he was quite rational, although unable to control the spasmodic motions of the muscles of his extremities, which were thrown about, and much distorted. Cupping, and other depleting measures, brought him into a quiet state; and he expressed himself as feeling much better. On the evening of the 9 th he was suddenly seized with a fit resembling epilepsy, which soon however assumed a confirmed apoplectic character, attended with complete insensibility, stertorous breathing, and general convulsions. He died the following evening.

Inspection forty-three hours after death.-Brain. The convolutions were much flattened, and closely pressed together. The blood-vessels were almost entirely empty. The membranes were quite dry, and the ventricles appeared to be almost obliterated, and would scarcely contain a dram. The structure of the brain was generally hard, firm, and of a pinkish hue. It weighed 3 lbs. 9 oz.

Thorax.-Heart natural. The lungs were gorged 
with blood, and pus was found in the bronchi. This dissection was reported by Mr. Jorden.

Remarks.-This is an instance of hypertrophy to a considerable extent, the brain weighing $3 \mathrm{lbs} .9$ oz., containing little or no blood in its vessels, and no serous fluid between the membranes or in the ventricles. The patient's symptoms appear to be strictly apoplectic, and the examination of the brain would no doubt afford to many pathologists another instance of a person dying with all the marked symptoms of apoplexy, and the dissection developing a perfectly healthy state of the brain. But I think that a patient consideration of the facts I have adduced in this paper, and in a former one which was read to the Society, leads to the more just and rational explanation of the phenomena, that the brain was in a state of hypertrophy, and that a very small additional compression from blood would occasion death by simple sanguineous apoplexy. This case bears a striking analogy to the preceding one, No. II.

\section{CASE I V.}

Hypertrophy of the Brain; Pulmonary Tubercles; Enlargement of the Heart; Dilatation of the Right Ventricle; Sudden Death.

James Tipton, æt. 40. Admitted Dec. 31. He has cough, dyspnoea, purulent expectoration, and diarrhœa. He died rather suddenly, after rising from bed. 
Inspection, Jan. 8, fifteen hours after death.Head. There was a considerable quantity of fluid in the cavity of the arachnoid, and in the sub-arachnoid tissue. There were two large bladders on the superior margin of each hemisphere, which seemed to have broken down the filamentous tissue between the pia mater and arachnoid. The brain was remarkably turgid with blood, was firm, and cut like ground-rice pudding. Weight 3 lbs. 7 oz.

Thorax.-The lungs were studded throughout with tubercles, and there were several small cavities in different-parts of the lungs. Heart large, with considerable dilatation of right ventricle.

Remarks.-The symptoms of this patient, up to the fatal attack, were referable to the disease of the heart and lungs. His sudden death may be attributed either to the state of the heart or to the state of the brain; but the latter I think is more probable, from the congested state of the brain, its firm consistence, and its weight, 3 lbs. 7 oz. It is probable that the obstructed circulation in the brain, occasioned by extensive and encroaching diseases of the heart and lungs, may in many instances tend to produce hypertrophy of the brain.

$$
\text { CASE } V .
$$

Hypertrophy of the Brain; Phthisis Pulmonalis ; Ramollissement.

Charles Russell, æt. 24. Admitted with the of- 
dinary signs of pulmonary tubercles, which had been attended with occasional hæmoptysis, and frequent pleuritic attacks. He complained of headache, and was delirious during the last four days.

Inspection, thirty hours after death, March 7th, 1834.- - Head. The convolutions of the brain were flattened to an extreme degree. There was no fluid between the membranes, and but little in the ventricles. The brain appeared increased in bulk, particularly in the medullary portion. There was ramollissement of the centre of the posterior lobes of the cerebrum. The septum lucidum, also; and the fornix, were softened nearly to a pulpy state. Weight, 3 lbs. 5 oz.

Thorax.-Lungs beset with tubercles and small cavities. A small ulcer on the mucous membrane of the larynx.

\section{Abdomen.-Ulceration of small intestines.}

Remark.-In this case the brain weighed $3 \mathrm{lbs}$. 5 oz., in a consumptive patient, who suffered headache and delirium during the last four days of life. Inflammation of the substance of the brain had also taken place, and occasioned the ramollissement in the medullary portion of the posterior lobes, and the pulpy state of the septum lucidum and fornix. 


\section{A SE VI.}

Hypertrophy of the Brain; flaccid Heart; sudden Death.

Elizabeth Garratt, æt. 70, was admitted into the surgical wards, and was under treatment for iritis. She was not known to suffer any other affection. After tea, March 15th, in her ordinary state of health, she dropped down and died suddenly.

Inspection, twenty hours after death.-Brain. The arachnoid was milky, and there was some serous effusion in the sub-arachnoid tissue. The blood-vessels were but little dilated, and there was very little blood in the substance of the brain. The medullary matter of the cerebrum was remarkably white, and cut like hardened custard. No other disease in the brain. Weight, 2 lbs. 15 oz.

Thorax.-The muscular structure of the heart was remarkably flaccid. No other change. Lungs healthy.

Abdominal viscera healthy.

Remarks.-This patient, aged 70, died suddenly, and on dissection a flaccid state of the heart was found, and the appearance of the brain strikingly denoting hypertrophy of that organ; - the bloodless state and white colour of the brain, with the consistence resembling coagulated albumen, and the weight, $2 \mathrm{lbs.} 15 \mathrm{oz}$., voL. XIX. 
much beyond the average for her age. Several instances are on record of sudden death, in which nothing is reported to have been observed but a flaccid or an attenuated state of the muscular structure of the heart, without blood or coagula in the cavities, and sudden death has been attributed to this cause; but in this case it is far more likely to have occurred from the hypertrophous state of the brain, and it is not unfair to suppose that this condition of the brain may have been overlooked in similar cases*.

\section{A SE VII.}

Hypertrophy of the Brain; diseased Kidney; Death from diffuse Inflammation.

Mary Catlin, æt. 29, admitted with the second attack of general dropsy from diseased kidney : a tall woman, accustomed to hard labour. She was attacked with erythematous œdema of the face, which rapidly extended to the left arm, and destroyed her.

Inspection, forty-four hours after death-Head. Brain very dense; convolutions flattened; ventricles small and dry; the absence of fluid in the brain was very remarkable. Weight, $3 \mathrm{lbs} .2$ oz.

Kidneys enlarged; red granular disease in both.

* Vide " An Account of Three Cases of Sudden Death, with the Appearances on Dissection, and some additional Observations, by T. Chevalier, Esq.," in Vol. I. of the "Transactions." 
Remarles. - The brain of a dropsical patient frequently partakes of the same state, and we find fluid in its cavities as well as in the thorax, abdomen, and extremities; but in this case all the signs of hypertrophy of the brain were present without any fluid. The patient suffered general dropsy from granular kidneys, and died in consequence of diffuse inflammation of the face and left upper extremity.

$$
\text { CASE VIII. }
$$

Hypertrophy of the Brain; Congestion of the Blood-vessels; no Fluid; Death from malignant Cholera.

Margaret Hảstie, æt. 48, was taken suddenly at 8 a. m., Dec. 3d, 1832, with the symptoms of a severe form of malignant cholera. She lived twenty-six hours after the attack.

Inspection, Dec. 4th.-Head. The blood-vessels of the membranes and substance of the brain were highly loaded. No fluid was found between the membranes or in the ventricles. The roof of the right ventricle adhered to the corresponding part of the corpus striatum. The cranium appeared well filled, the brain was large, and weighed $3 \mathrm{lbs} .5 \mathrm{oz}$. The brain had a peculiar appearance when cut into, resembling coagulated albumen with a quantity of plaster of Paris mixed with it.

Thorax.-Heart hypertrophied; a number of small 
tumours on the surface of the lungs. Some tubercles and one or two cavities were found in the lungs.

Abdomen.-Cholera fluids in the intestine; in some parts feculent matter. Extensive thickening and ulceration of the ileum and cœcum.

Remarks. - In this case of malignant cholera the usual congested state of the vessels of the brain was found, but there was no serous fluid, and the brain was large, and weighed 3 lbs. 5 oz. Its texture presented the appearance of coagulated albumen with some heavy powder mixed with it, and in all respects a state of the organ resembling hypertrophy of the brain.

¿. CASE IX.

Hypertrophy of the Brain, in a Child at. 11 months.

Dec. 14, 1832, I was requested by Mr. Jorden, of Belgrave Street, to accompany him to examine the body of Caroline Bays, a child, aged eleven months. I received from him the following particulars of the child's history. Her head was observed to increase in size in an unusual degree about six weeks after birth : the general health was good until about three days ago, when she became feverish, with rapid pulse and constipated bowels. At this time the head was much enlarged, the forehead being remarkably prominent; the fontanels enlarged, firm, and 
tense to the touch; superficial veins enlarged; the eyes were generally fixed in a downward direction, more especially the left. The child was constantly moaning, and rolling its head from side to side and tossing its hands about. Convulsive twitchings latterly came on. The mother has had four children, all of whom died either a few days or weeks after birth. Leeches, cold lotions, and purgatives weré used without effect.

Inspection, eight hours after death.-Head. The fontanels were large, sunk, and flaccid: cranium of rather unusual thickness. The circumference of the cranium, after removing the integuments, at the largest axis measured seventeen inches and a half, and from one meatus auditorius internus, over the vertex to the other, twelve inches. The membranes and substance of the brain were bloodless. The brain was very much enlarged, and its consistence rather softer than usual. The ventricles contained about one ounce of fluid.

Thoracic and abdominal viscera were natural, with the exception of some enlarged mesenteric glands.

Remarks. - A case of hypertrophy in a child eleven months old, rapidly increasing soon after birth, and presenting all the signs of chronic hydrocephalus internus. The magnitude of the brain appeared to be nearly double that of a child of its age. The brain and membranes were found almost free from 
blood. From the soft state of the brain, it is probable that an inflammatory process had been going on during the latter period of the child's life.

The case related by Dr. Thomson in the Lancet, to which $I$ have before alluded, occurring in a child between four and five years old, bears some resemblance to the present case: the inflammatory state, and consequent ramollissement, had proceeded to a much greater length.

\section{CASE X.}

\section{Hypertrophy; bloodless Brain; Death from} Cholera.

Mary Ann Burk, æt. 10. Her mother reports she has always been a healthy child : has never had fits or any affection of the head. She has been quite healthy during the time she has been in the parochial school; the schoolmistress states that she is a very clever, intelligent child. She was attacked with all the characteristic signs of malignant cholera, and lived 68 hours in the cold stage without reaction. She was comatose, with tendency to delirium, but could be easily roused, and then would answer questions correctly.

Inspection.-Head. The cranium and sinuses of the dura mater were highly congested. When the calvaria was removed the dura mater appeared dis- 
tended and tense; this was more observable in consequence of the blood having escaped from the longitudinal sinus, which occasioned a depression, and the two hemispheres then appeared much elevated. There was no serous fluid effused between the membranes, or into the ventricles. The arachnoid and pia mater were quite dry, very thin, and not separable from one another. There was very little blood in the vessels of the pia mater, or in the substance of the brain. The pia mater adhered in some parts to the brain, and brought portions of the gray matter away on tearing off the membrane. The convolutious were all flattened, as in extreme cases of compression from fluids within the brain. The gray matter was softer than usual, both on the surface and in the central parts. The medullary matter was remarkably white. The substance of the brain cut like blanc-mange or thick custard. Weight, 2 lbs. 14, oz.

Thorax.-Heart gorged with fluid blood. Lungs healthy, but slightly adherent.

Abdomen.-The usual appearances in the intestines of cholera patients.

Remarks.-This child died from malignant cholera, and on examining the brain the usual highly congested state was wanting; on the contrary, the brain appeared large, and disproportionate to the size of the cranium, the membranes were perfectly dry, and 
there was no serous fluid in them or in the ventricles : the white matter presented all the signs common to other cases of hypertrophy. The softening of the gray matter, both in the central parts and on the surface, and that of the latter adhering to the pia mater, would seem to denote inflammation; but the child remained in a state of collapse from the period of its seizure to its death, 68 hours. It is probable that the supervention of extensive inflammation of the brain might so far oppress the brain as to impede the reaction of the powers of the system.

\section{CASEXI.}

$\checkmark$

Hypertrophy of the Brain; Hooping-cough;

Death from Pneumonia.

Mary Monroe, æt. 3. When first visited she was suffering from hooping-cough, which had existed about a fortnight. Severe pneumonia supervened, for which leeches, antimony, \&c., were used, but without any effectual relief. She was quite insensible during the last 24 hours, with coma and occasional convulsions.

Inspection, Dec. 20th, 1832.-Head. There was excessive fulness of all the veins and sinuses in the skull. When the calvaria was removed, the brain appeared swollen and protruding beyond the margin of the section made by the saw. The convolutions were very flat, and the substance was firm, and of a consistence to 
the knife resembling cream-cheese. The arachnoid was unctuous or sticky, and the pia mater adhered to the surface of the cerebrum. There was no fluid between the membranes or in the ventricles. The brain weighed 2 lbs. $15 \mathrm{oz}$.

Thorax.-Left ventricle and also the right appeared somewhat enlarged. The lungs were hepatized, going on to the soft and purulent stage. The bronchi were inflamed and contained much mucopurulent fluid.

Abdomen.-The mesenteric glands were diseased.

Remarks.-This is a case of remarkably large brain in a child three years old, weighing 2 lbs. 15 oz. The skull and sinuses were congested with blood, but the substance of the brain was not so. There was no fluid in the membranes or ventricles, and all the other signs of hypertrophy were present. As in the case immediately preceding this, the symptoms and traces of inflammation of the substance of the brain were observed, which was most probably influenced by the state of the thoracic viscera consequent on hooping-cough and pneumonia.

\section{CASE XII.}

Hypertrophy of the Brain; Death from maligmant Cholera.

G. N., a girl æt. 10, had suffered one of the 
most severe attacks of malignant cholera, from which she appeared to be recovering; she, however, had a relapse, and speedily fell a victim to the disease.

Inspection.-Brain. There was little or no fluid found in the membranes or ventricles: the brain appeared enormously enlarged, and weighed $3 \mathrm{lbs}$. 12 oz.

Abdomen.-The usual strongly marked signs of malignant cholera were found in the alimentary canal.

Remarks. - This little girl had almost entirely recovered from a severe attack of malignant cholera, when she relapsed and was carried off by the disease. She was observed to have a remarkably large head, but was perfectly intelligent in all respects. The weight of the brain, $3 \mathrm{lbs} .12 \mathrm{oz}$., is very remarkable for a child of ten years old.

\section{Partial Hypertrophy.}

It is frequently found that parts of the brain are enlarged beyond their ordinary size, either originally, or produced in after periods of life. The three following cases are examples of this partial enlargement of the brain.

$$
\text { C A S E X III. }
$$

Hypertrophy of one Hemisphere; old Apoplectic Cysts.

Esther Walters, æt. 60. She is reported to have 
had a paralytic attack about two years ago, from which she was much relieved. She continued to move about until within ten days of her admission. Signs. of arachnitis came on with coma, and she died June 21 st.

Inspection. - Head. The left hemisphere occupied about two-thirds of the space allotted to the cerebrum. The left corpus striatum was enlarged to twice its usual size : the right corpus striatum was diminished in size. There were two apoplectic cysts in the left hemisphere and one in the right, of different dates.

\section{CASE XIV.}

Partial Hypertrophy, affecting the Corpora Striata, one Thalamus, and the Tuber Annulare.

C. D., æt. 60. A lunatic for twenty years with lucid intervals; he was approaching to a state of fatuity; he complained much of great weakness of the lower extremities. He had a carcinomatous disease of the lower lip, which Mr. Perry removed. The wound looked well at the time of his death.

Inspection.-Head. The skull was remarkably hard : there was considerable serous effusion between the membranes, and a large quantity in the intergyral spaces. On opening the ventricles, the corpora striata appeared pressed much closer to each other than usually. The right corpus striatum was twice 
its ordinary size, the left slightly enlarged. The left thalamus was very much enlarged. The tuber annulare appeared half as large again as usual: the crura cerebri were also enlarged.

\section{CASE XV.}

Delirium Tremens; much Fluid; disproportionate size of posterior Lobes of Cerebrum. Hypertrophy of Os Frontis.

George Nigh, æt. 29. Talks incoherently. Universal tremor of the limbs. The delirium increased and he gradually sank. He had been pot-boy at a public house, and much addicted to drinking.

Inspection, Dec. 12th, 1832, seventeen hours after death. - The skull was remarkably thick, and in the frontal region about half an inch. There was much fluid between the membranes, and several ounces in the ventricles. The arachnoid was white: The skull was much larger than usual in the occipital region, which was occupied by the enormously disproportionate size of the posterior lobes of the cerebrum. The brain weighed 3 lbs. $8 \mathrm{oz}$.

Summary of the Appearances in the three preceding Cases.

No. 13. The left hemisphere occupied two-thirds of the space allotted to the cerebrum; there was 
hypertrophy of the left corpus striatum, with atrophy of the right.

No. 14. There was hypertrophy of the corpora striata, the left thalamus, the tuber annulare, and the crura cerebri.

No: 15. The brain was heavy, weighing $3 \mathrm{lbs}$. $8 \mathrm{oz}$. The posterior lobes of the cerebrum were very much larger than natural : there was also hypertrophy of the os frontis.

The state of the brain which I have described, admits of division into two kinds; one, a state of mere enlargement or addition of particles, without any appreciable or apparent difference from the ordinary state of the organ; this appears to be connate, or connected with rickets, manifesting itself very early, and attaining in some instance a very great magnitude. In the other and most important form of hypertrophy, the weight of the brain is sometimes very materially increased; but in this case it is not of so much value as the bloodless state of the brain, its freedom from serous effusion, its very white and albuminous texture, and the flattening of the convolutions, \&c., which I have so often noted.

If we could ascertain with some degree of accuracy the average weight of the healthy brain at various periods of life, we should then be able to estimate 
more nearly the extent of hypertrophy, so far as the circumstance of weight is concerned; but almost all the attempts that have hitherto been made have been ineffectual and liable to error. The method to fix the weight of the brain on a scale, comparing it with the weight of the body, does not remove the difficulty, for some very thin subjects, exhausted by wasting diseases, have brains above the average weight, and it is well known that some of the heaviest bodies possess very small brains.

Haller states that in one child, a boy of six years old, he found the brain to weigh 2 lbs. $28 \frac{1}{2}$ drams, the weight of the body being $50 \mathrm{lbs}$., or about $\frac{1}{22}$ : in other instances he found the weight of the brain to be $\frac{1}{25}$, and $\frac{1}{30}$ the weight of the body. He further observes, "Homini cerebrum aliquando libram cum sèmisse in adulto homine non superavit: alias fuit trium l., et trium 1 . atque 8 unciarum cum $\frac{1}{\$}$, et quatuor librarum; quatuor porro et unciarum trium; quatuor et unciarum tantumdem, quatuor ad quinque ; quinque denique et ultra."*

Soemmerring in the section "Pondus Cerebri," remarks, "Cerebrum et cerebellum, resecta medulla spinali statim pone nervum lingualem medium pondo sunt librarum duarum ad tres libras, sunt enim alia cerebra pondere librarum duarum, et unciarum quinque cum dimidia, alia librarum trium et unciarum

* Elementa Physiologiæ, Tom. IV., p. 10. 
trium cum tribus quartis." * His "Tabula Baseos Encephali " is taken from a child three years old.

The Wenzels, in their great work on the structure of the brain, state "Pondus encephali humani quale id de quinto vitæ anno ad summam usque hominis senectutem plerumque invenitur, pondus viginti quatuor millium granorum non superat." Again; "Totius cerebri pondus inter viginti et viginti-duo millia granorum plerumque variat." $\uparrow$ They give a table of the weight of nineteen brains of various ages, from a foetus of five months up to old age, 88 years.

Sir William Hamilton has taken great pains to ascertain the weight of the brain, and concludes, " that the adult male encephalos is heavier than the female; the former nearly averaging, in the Scot's head, $3 \mathrm{lbs} .8 \mathrm{oz}$. troy, the latter $3 \mathrm{lbs} .4 \mathrm{oz}$., the difference 4. oz. In the male, about one brain in seven is found above $4 \mathrm{lbs}$. troy; in the female hardly one in a hundred." Sir William founds this and other conclusions, "on an induction drawn from above sixty human brains,-from nearly three hundred human sloulls, of determined sex, the capacity of which, by a method I devised, was taken in sand, and the original weight of the brain thus recovered." $\$$ I

* De. Corp. Hum. fabrica, Tom. IV., p. 38.

† J. et C. Wenzel, De Penitiori Structura Cerebri, p. 267.

$\ddagger$ The Anatomy of the Brain, \&c., by Dr. Monro. 1831. p. 4. 
think the weight of the brain cannot be fixed by ascertaining the capacity of the skull, by any means however accurate; it is open to a source of fallacy, which appears obvious on inspecting the last column of Table I.

I have endeavoured to ascertain the weight of the brain in a great number of dissections of persons of all ages and both sexes, who died of diseases of almost every description, whether cerebral or otherwise : in some the brain was healthy, in others diseased in different degrees and forms.

The annexed Table, No. I., is taken from 253 dissections of the brain.

The first column specifies the sex.

The second, the age.

The third, the disease occasioning death.

The fourth, the weight of the brain.

The fifth, a brief notice of the appearances observed on dissection which might influence the weight.

In each case the weight of the whole encephalon is taken, the dura mater being removed; the weight used is avoirdupois. 


\section{Table $\mathbf{I}$.}

Shewing the age, sex, fatal disease, weight of the brain, and other pathological appearances in 253

\section{cases.}

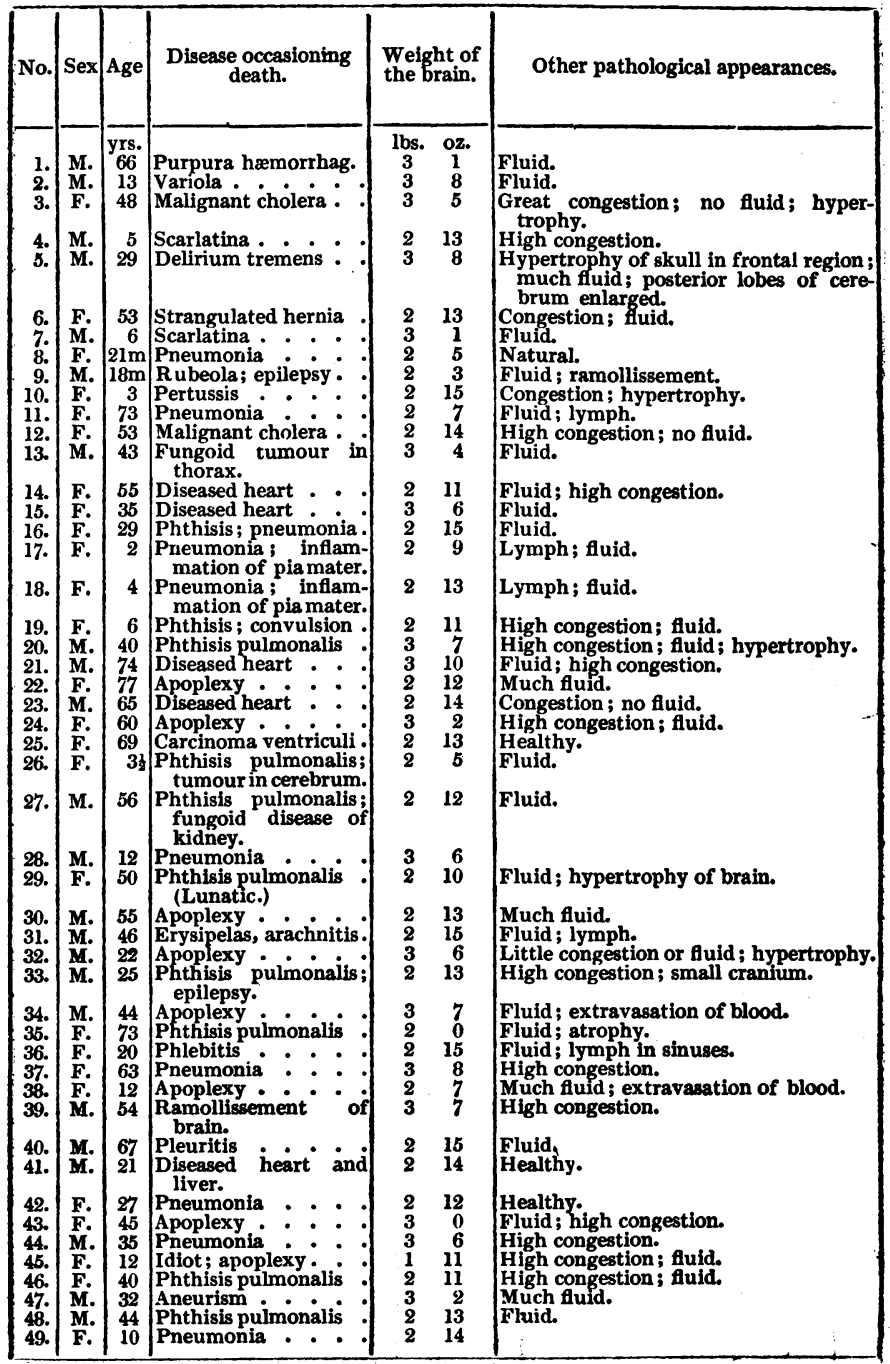




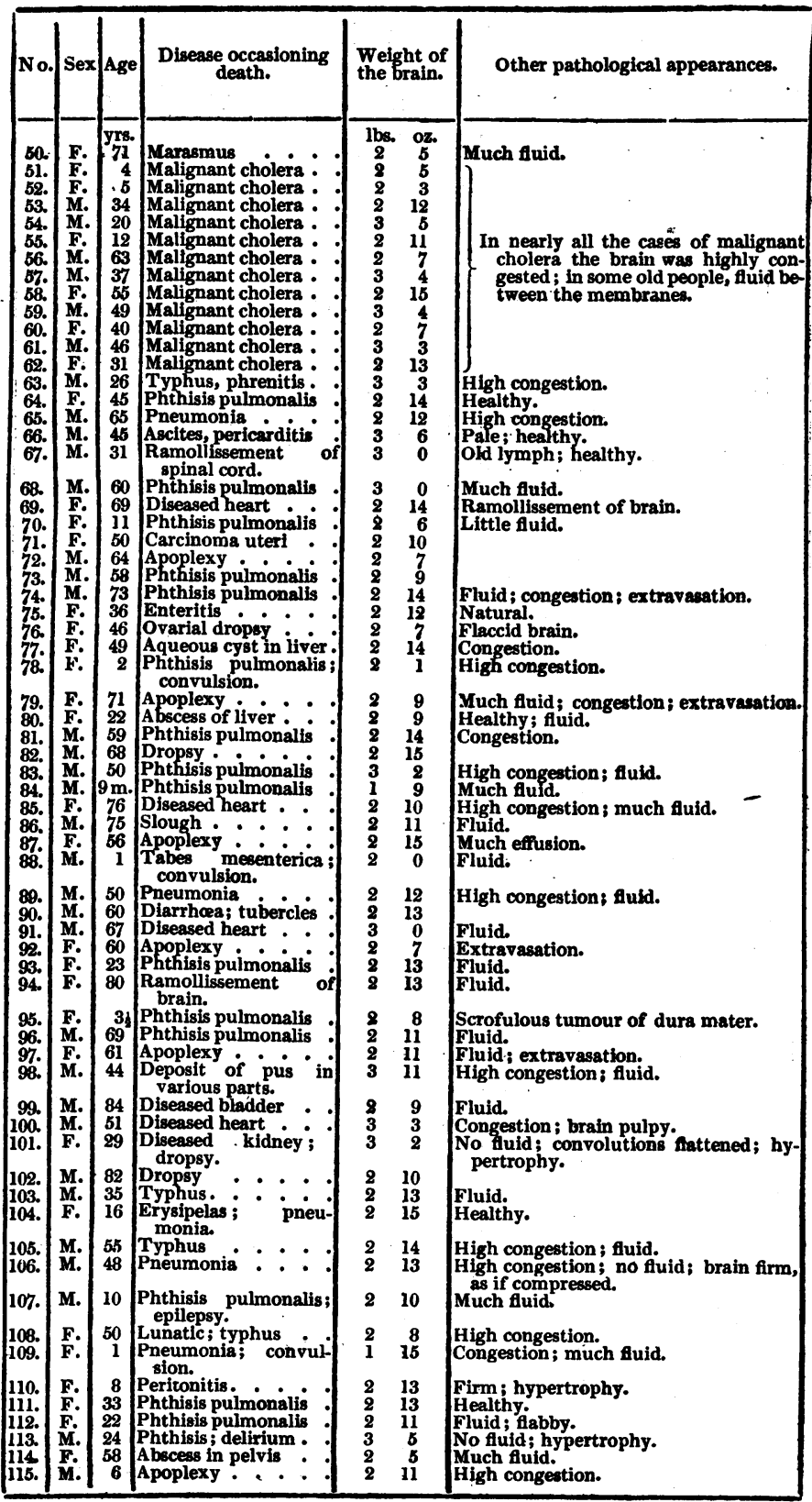




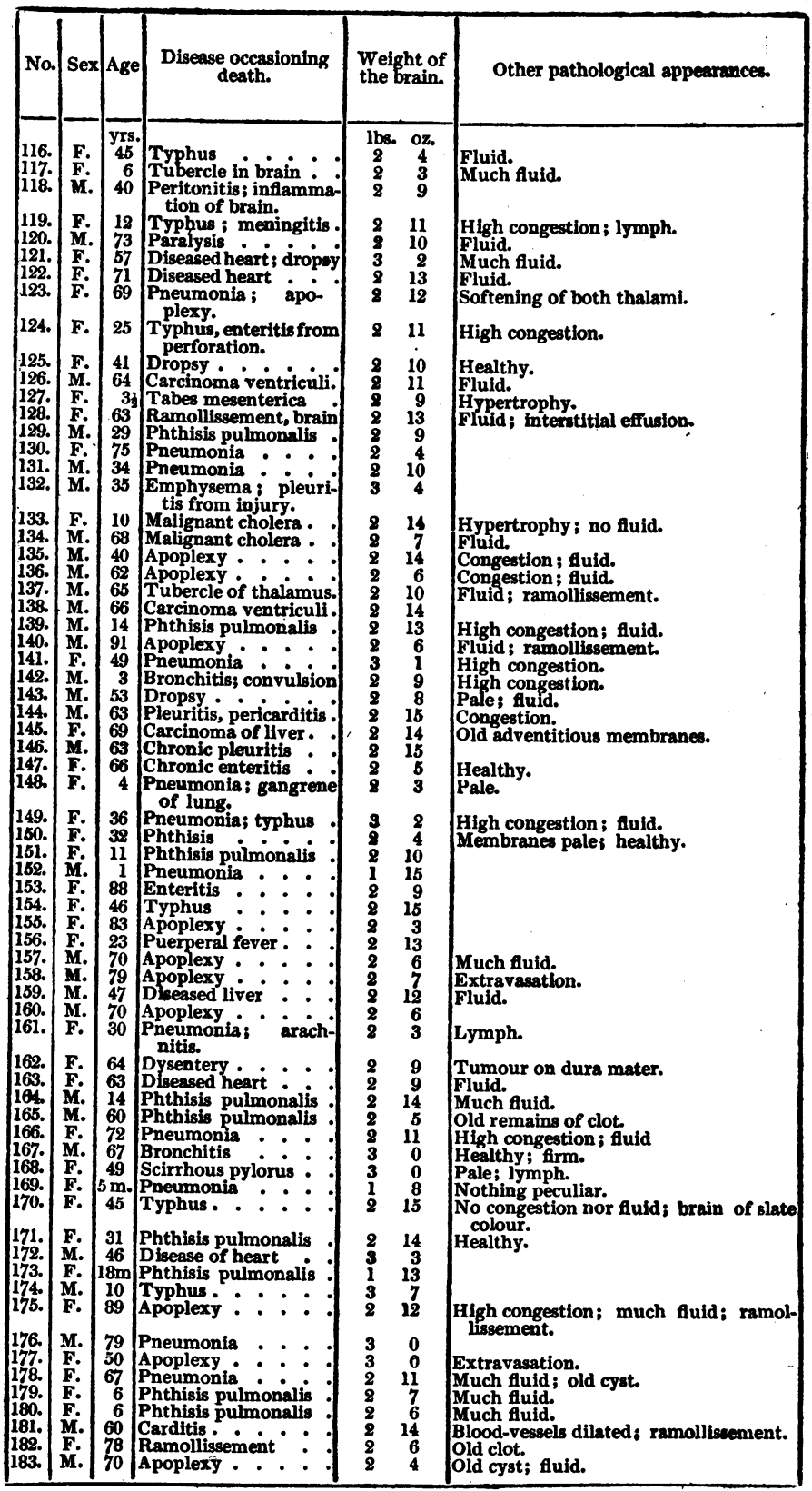

A 12 


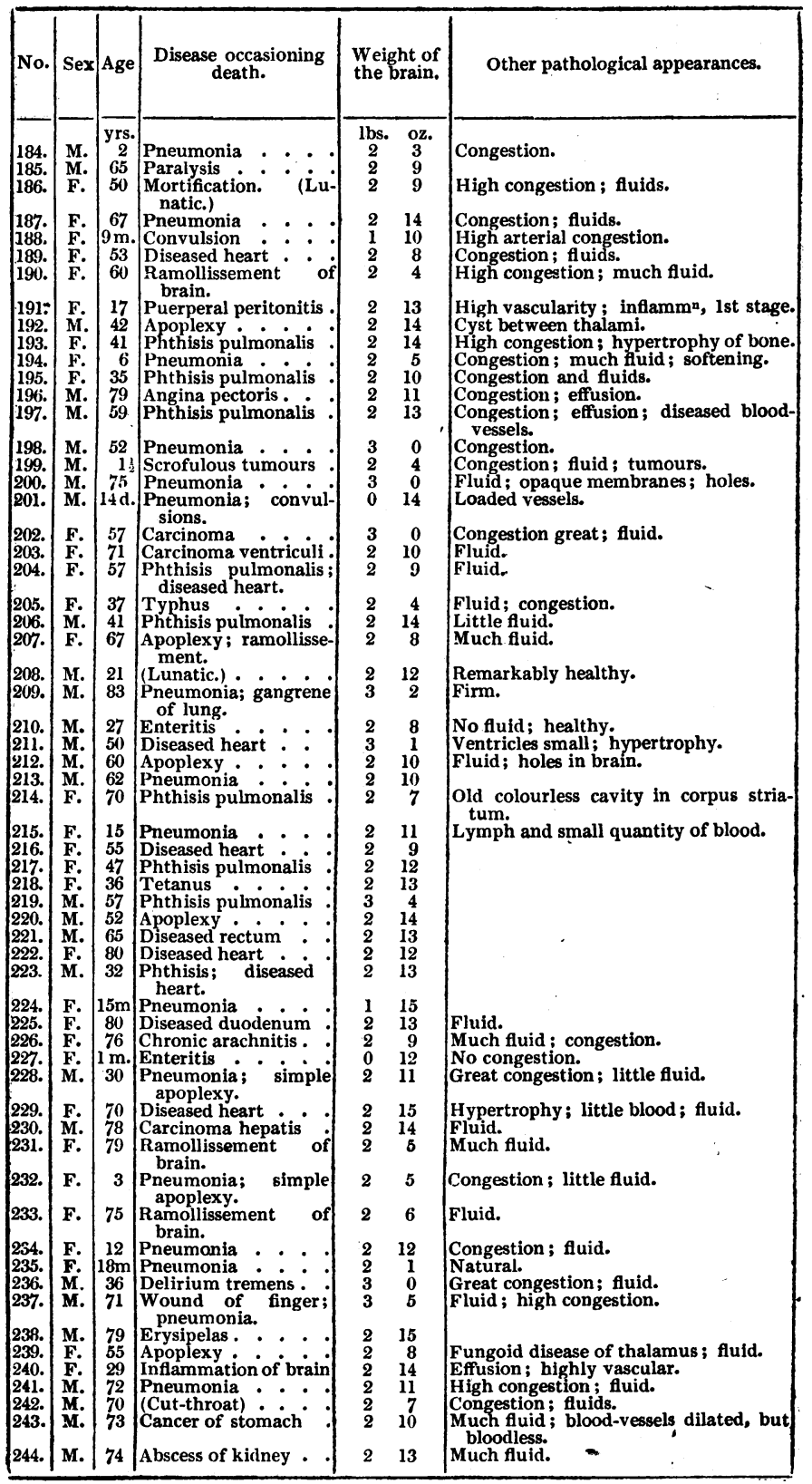




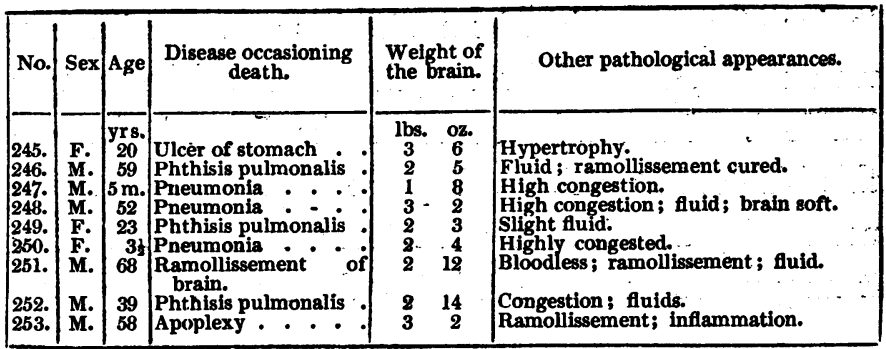

\section{TABLE II.}

Shewing the weight of the brain in seven cases below one year old.

\begin{tabular}{|c|c|c|}
\hline Age. & Weight & of brain. \\
\hline 14 days. & $\begin{array}{c}\text { lbs. } \\
\text { 0 }\end{array}$ & $\begin{array}{l}\text { oz. } \\
14\end{array}$ \\
\hline 28 days . . . . . . & $\mathbf{0}$ & 12 \\
\hline 5 months . . . . & 1 & 8 \\
\hline 5 months . . . . & 1 & 2 \\
\hline 5 months $\ldots \ldots$ & 1 & 8 \\
\hline 9 months $\ldots \ldots$ & 1 & 9 \\
\hline 9 months $\ldots \ldots$ & 1 & 10 \\
\hline
\end{tabular}

In the last column of Table I., a few of the appearances observed on dissection, and which might possibly influence the weight of the brain, are shortly mentioned. Where the words "fluid". and "congestion" are used simply, they will be understood to mean in a small degree, and such as might not, in most cases, have prevented the brain being considered healthy. The majority of the cases are of course taken from 
brains of persons in whom diseases not cerebral, of various degrees and forms, existed, as will be seen in Table I. I am well aware of the imperfections of this Table, but perhaps they are imperfections which necessarily attach to the subject; however, I hope it may prove a useful statistical document.

In Table No. III., I have attempted to ascertain the average weight of the brains in the preceding Table, No. I., according to a scale of the ages of the subjects, excluding six cases of hypertrophy, without at present referring to the diseases which occasioned death, or to the morbid state or otherwise of the brain.

It will be observed that the number of brains examined in the several divisions of this Table varies very much, and this must be considered one of its imperfections.

The inference from this Table is, that the average weight of the brain goes on increasing from one year old to twenty; between twenty and thirty, there is a slight decrease in the average; afterwards it increases and arrives at the maximum between forty and fifty; after fifty, to old age, the brain gradually decreases in weight. Many of the results differ from those of preceding observers. 


\section{Table III.}

Shewing the average weight of the brains in Table I., arranged on a scale according to the age of the subjects.

\begin{tabular}{|c|c|c|c|c|}
\hline Age. & $\begin{array}{l}\text { Number } \\
\text { weighed. }\end{array}$ & $\begin{array}{c}\text { Heaviest } \\
\text { brain. }\end{array}$ & $\underset{\text { brain. }}{\text { Lightest }}$ & Average. \\
\hline $\begin{array}{l}\text { yrs. yrs. } \\
1 \text { to } 2\end{array}$ & 9 & $\begin{array}{cc}\text { lbs. } & \text { oz. } \\
2 & 5\end{array}$ & $\begin{array}{cc}\text { lbs. } & \text { oz. } \\
1 & 13\end{array}$ & $\begin{array}{ll}\text { lbs. } & \text { oz. } \\
2 & 1 \text { nearly }\end{array}$ \\
\hline 2 to 3 & 3 & 29 & 21 & $24 \frac{1}{3}$ \\
\hline 3 to 4 & 5 & 29 & 24 & $26 \frac{1}{5}$ \\
\hline 4 to 5 & 3 & 213 & 23 & 2 \\
\hline 5 to 10 & $\mathbf{9}$ & $\begin{array}{ll}3 & 1\end{array}$ & 3 & $8 \frac{4}{9}$ \\
\hline 10 to 15 & 14 & 38 & 111 & $2,12 \frac{4}{14}$ \\
\hline 15 to 20 & $\mathbf{3}$ & 215 & 211 & 213 \\
\hline 20 to 30 & 19 & 35 & 23 & $2 \quad 12 \frac{1}{19}$ \\
\hline 30 to 40 & 22 & 36 & 3 & $2 \quad 13 \frac{1}{2} \frac{1}{2}$ \\
\hline 40 to 50 & 29 & 3. 11 & 4 & $2 \quad 14 \frac{2}{2} \frac{9}{9}$ \\
\hline 50 to 60 & 35 & 7 & 25 & $2 \quad 13 \frac{2}{35}$ \\
\hline 60 to 70 & 42 & 38 & 24 & $2 \quad 11 \frac{34}{4}$ \\
\hline $\left.\begin{array}{c}70 \text { and } \\
\text { upwards }\end{array}\right\}$ & 44 & 310 & 20 & $2 \quad 10 \frac{5}{44}$ \\
\hline
\end{tabular}


In the following Table, I have selected a few cases, with the age, disease occasioning death, and the weight, the brain being perfectly healthy.

\section{TABLE IV.}

Healthy brains.

\begin{tabular}{|c|c|c|c|c|}
\hline No. & Sex. & Age. & Disease occasioning death. & $\begin{array}{l}\text { Weight of } \\
\text { brain. }\end{array}$ \\
\hline $\mathbf{1}$ & F. & $\begin{array}{l}\text { yrs. } \\
11\end{array}$ & Phthisis pulmonalis. & $\begin{array}{cc}\text { lbs. } & \text { oz. } \\
\mathbf{2} & \mathbf{6}\end{array}$ \\
\hline 2 & F. & 16 & Erysipelas ; pneumonia & 215 \\
\hline 3 & M. & 21 & $\begin{array}{l}\text { Diseased heart, liver, } \\
\text { intestines. }\end{array}$ & 214 \\
\hline 4 & F. & 22 & Abscess of liver. & 9 \\
\hline 5 & F. & 27 & Pneumonia. & 212 \\
\hline 6 & F. & 30 & Phthisis pulmonalis. & 24 \\
\hline 7 & F. & 31 & Diseased heart. & 214 \\
\hline 8 & F. & $\mathbf{3 3}$ & Phthisis pulmonalis. & 213 \\
\hline 9 & F. & 36 & Chronic enteritis. & 212 \\
\hline 10 & F. & 45 & Phthisis pulmonalis. & 214 \\
\hline 11 & M. & 45 & Pericarditis; dropsy. & 3 \\
\hline 12 & F. & 50 & Phthisis pulmonalis. & 210 \\
\hline 13 & M. & 56 & $\begin{array}{l}\text { Phthisis pulmonalis ; } \\
\text { fungoid kidney. }\end{array}$ & 212 \\
\hline 14 & F. & 69 & Carcinoma ventriculi. & 213 \\
\hline
\end{tabular}


From this limited Table, it appears the weight of eight out of twelve adult healthy brains approaches very nearly to uniformity.

Troy weight was used by Sir William Hamilton in his observations, and he found that the average weight of the adult male brain was $3 \mathrm{lbs} .8 \mathrm{oz}$, that of the female $3 \mathrm{lbs}$. $4 \mathrm{oz}$. One pound avoirdupois being equal to $14 \mathrm{oz} .11 \mathrm{dwts.} 15 \frac{1}{2}$ grs. troy, and as most of the brains in Table IV. were females, the weight very nearly corresponds with Sir William's conclusions.

I subjoin a short account of several cases in which the brain was found unusually large and heavy from various causes, but which did not constitute hypertrophy. The brain in most of the cases was greatly increased in weight by the enormous quantity of blood contained in the dilated vessels.

I. A boy, aged 13, died delirious, on the fifth day of small-pox. On examining the brain, the tunica arachnoidea was found thickened throughout. Fluid in the sub-arachnoid tissue, and $4 \mathrm{oz}$. in the ventricles. The substance of the brain was firm throughout; weight, 3 lbs. 8 oz.

II. A boy, æt. 6, had a smart attack of scarlet fever; at first he appeared doing well, was afterwards delirious for some days, and then sank rapidly. The brain was found natural, excepting a 
small quantity of fluid ; weight, $3 \mathrm{lbs} .1 \mathrm{oz} . \quad$ Extensive pneumonia and hepatization of lungs.

III. A girl, æt. 21 months, had just recovered from the measles with pneumonia; a second attack of pneumonia appeared, and the child rapidly sank. Brain healthy; weight, 2 lbs. 5 oz.

IV. A boy, æt. 18 months. Admitted five weeks ago with measles : he is now much emaciated, and diarrhœa continues; latterly he has had frequent fits ; pupils remarkably dilated during the fit. Dissection.-Fluid was found in the membranes and ventricles. Softening of fornix and testes. Pineal gland twice its usual size. Weight, 2 lbs. 3 oz.

V. A man, æt. 74, was much relieved, three months ago, from general dropsy depending on diseased heart, by bleeding and diuretics. He was again brought to the Infirmary in an extremely depressed state, and died before he could be put to bed. High congestion in the brain, and effusion in the sub-arachnoid tissue. Arteries tortuous and ossified. Brain firm; weighed 3 lbs. $10 \mathrm{oz}$.

VI. A boy, æt. 12, who died of pneumonia; brain weighed 3 lbs. 6 oz.

VII. A woman, æt. 63. Consolidation of the lungs from repeated attacks of pneumonia : emphysema. The brain was found very firm, great con- 
gestion throughout, and the veins on the surface distended with fluid blood; weight, 3 lbs. 8 oz.

VIII. A woman, æt. 60, in whom were found remains of severe pleuritic attacks. OEdema and emphysema of the lungs; the brain weighed 3 lbs. 2 oz.

IX. A girl, æt. 2. A sickly emaciated child, with continued diarrhœea; convulsions twenty-four hours before death; contraction of flexors of the thumbs. The brain was highly loaded with blood, of a pink colour: the ventricles dilated; weight, 2 lbs. 1 oz.

X. A boy, æt. 1, emaciated with continued diarrhœa, died in a convulsion fit. A large quantity of fluid in the sub-arachnoid tissue, and in the substance of the brain; weight, 2 lbs.

XI. A girl, æt. 8, subject to diarrhœea, died from peritonitis. Brain very firm, weighed 2 lbs. 13 oz.

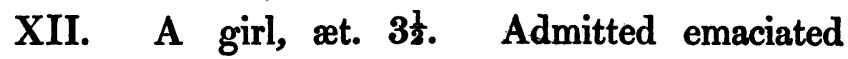
from mesenteric disease. Attacked with malignant cholera, and died in six days. Brain large, weighing 2 lbs. 9 oz. Membranes thin and dry. Pia mater adherent. Gray matter, very soft, and apparently in greater quantity than usual, very vascular, and mottled in the central parts. 
XIII. A boy, æt: 3. Hóoping-cough; died in convulsions. Surface of the brain flattened; bloodvessels very turgid; the brain weighed 2 lbs. 9 oz.

XIV. A boy, æt. 14. Phthisis pulmonalis; much effusion from the membranes and into the ventricles; weight, 2 lbs. 14 oz.

XV. A girl, æt. 2. Inflammation of pia mater ; pneumonia; sero-purulent effusion; weight, 2 lbs. 9 oz.

XVI. A girl, æt. 4. Inflammation of pia mater; pneumonia; sero-purulent effusion; weight, 2 lbs. 13 oz.

\section{II.}

\section{Atrophy of the Brain.}

Every one familiar with the dissection of the brain, must frequently have noticed a marked diminution in the magnitude of the brain, in persons of advanced life, whether the subjects have suffered apoplexy, ramollissement, or any other disease of the brain; or in cases where no evidence of previous disease of the brain appears from a careful examination, or from the history of the patient. It is equally a matter of observation that in young persons, and those in the meridian of life, who have suffered from long continued emaciating diseases, the brain has very frequently undergone a degree of wasting in some re- 
spects corresponding with that of the other parts of the body. In this state the brain has suffered a general or perhaps uniform wasting in all its parts, in both the gray and white matter.

The marks by which this state of wasting may be known are, a particular collapse or shrinking together of the convolutions when the horizontal section is made, so as to cause the white matter to appear depressed, and not to present the even surface observed in a firm and healthy brain;-a quantity of serous fluid may be squeezed out of the interstitial tissue of the brain;-a stringiness of the substance, arising from the absorption of the pulpy matter, and the probable thickening of the filamentous tissue*; flaccidity of the brain in some instances; a dilated state of the blood-vessels, whether empty or filled with blood; the presence of serous fluids in the ventricles or membranes, and hypertrophy of the bones of the skull.

In partial atrophy we sometimes observe one hemisphere of the cerebrum to be very much less than its fellow; one lobe of the cerebellum also to be diminished in comparison with the other; sometimes parts of the gray matter covering the convolutions are dwindled. Very frequent instances of partial

* Dr. Baillie has remarked that the brain is sometimes tougher and more elastic than usual, and that under these circumstances the ventricles were enlarged in size and full of water. Morbid Anatomy, p. 434. 
atrophy are met with in the corpora striata and in the thalami. The natural rounded form of the corpus striatum is rendered much flatter, and there are often furrows in it; the extent of its surface which appears in the ventricle is much contracted, and on cutting into it, the gray matter appears loose, and holes are frequently observed. The thalami are sometimes much wasted, the contiguous sides are widely separated, and instead of the perpendicular line of the lateral face of these bodies, it appears scooped or hollowed out; their rounded or upper surface is either flat or hollowed, and the ventricular margin presents a ridge instead of the usual convexity. One of the thalami, or one of the corpora striata, is sometimes atrophied, whilst its fellow retains its normal state, or is hypertrophied.

The blunted feelings, loss of memory, diminished mental power, feeble movements, muscular tremors, and probably impaired energy in the actions of the thoracic and abdominal viscera, may, I think, be accounted symptoms of cerebral atrophy in aged persons. Possibly the wasting of the brain in phthisis pulmonalis, and other emaciating diseases, may have some part in producing the muscular weakness, the diminished energy in all the functions of the system, and the general emaciation.

The chasm occasioned by the atrophied state of the brain, we observe to be sometimes filled up by serous fluid, and by deposits of bone on the skull : and the 
opinion is highly probable, that this excess of fluid and of bone is placed there to supply the deficiency.

The hypertrophy which takes place in the bones of the cranium is very frequently confined to the inner surface of the os frontis; in other cases it is more general. One of the specimens on the table was taken from a subject who died of diseased heart, dropsy, \&c., in whom a quantity of serous fluid was found in the brain, and the interior of the cranium was generally covered with an adventitious deposit of bone. This deposit, in most instances that $I$ have observed, is placed on the inner table of the skull : in other instances, the deposition appears to take place in the diploe, and to expand the tables of the bone.

The following are cases in which the brain was much diminished in size, either generally or partially.

$$
\text { CASE I. }
$$

Apoplexy; Hypertrophy of Os Frontis; Atrophy of the Brain.

Edward Burgess, æt. 70. About four months ago he was seized with apoplexy, attended with hemiplegia of right side, and loss of speech. Since the attack, he has never recovered the use of the paralysed side, but he has had occasional variations of sensation and motion. He soon shewed signs of childishness, which increased nearly to fatuity. He 
made frequent attempts to speak, and sometimes he succeeded in uttering a word or two.

Inspection, Jain. 13, 1835, ten hours after death. Head.-The cranium was thickened by a deposition on the inside of the os frontis, so as to diminish the capacity of the frontal region of the cavity: the corresponding parts of the anterior lobes of the cerebrum were diminished in size and flattened. There was considerable opacity of the membranes, and effusion into the ventricles and membranes. The right corpus striatum was flaccid and shrivelled, and of a reddish brown colour. Both the thalami were atrophied to about half their natural size. The remains of an apoplectic cyst were found in the left corpus striatum. Weight of the brain, $2 \mathrm{lbs} .4 \mathrm{oz}$.

Thorax._Right lung adhered firmly. Heart flabby but healthy.

This brain weighed 2 lbs. 4 oz.: the brain of a child two years old, examined the same day, who died of pneumonia, weighed 2 lbs. $3 \mathrm{oz}$.

Remarks. - In this case, the weight of the brain was six ounces and a half less than the average of forty-four brains of persons upwards of seventy years of age, detailed in a preceding Table. The patient was four months under observation; and it is most probable that from the time of the apoplectic attack 
the wasting of the brain began, and that it was progressive, and evidenced by his increasing childishness and approach to fatuity. The atrophy of the anterior lobes of the cerebrum, with its consequent hypertrophy of the os frontis, may account for the mental declension. The apoplectic cyst in the left corpus striatum corresponds with the right hemiplegia. Both the thalami presented remarkable instances of atrophy of these bodies.

\section{CASE II.}

Atrophy of the Brain; Ramollissement; Holes in the Brain; diseased Blood-vessels.

Joseph Lilley, æt. 91, suffered an apoplectic attack, arising from ramollissement, which soon carried him off.

Inspection, fifteen hours after death, Sept. 12, 1834. Brain.-A large quantity of fluid was contained in the dilated ventricles and between the membranes. The membranes presented various degrees of opacity and toughness: a large, softened spot was noticed in the right hemisphere. The thalami were much shrunk: there was an old deposit in the right corpus striatum, and many holes in various parts of the brain. The arteries of the brain were all more or less ossified, and other parts of the arterial system partook of this state, Weight, 2 lbs. 6 oz. 
Remarks.-On the same day, the body of a boy; æt. 14, who died from pulmonary tubercles, was examined. He was admitted in a dying state, a mere skeleton; drowsy, and affected with diarrhoea. Brain loaded with blood, membranes opaque, and fluid beneath. Weight, $2 \mathrm{lbs} .13 \mathrm{oz}$. Thus the weight of the boy's brain, æt. 14, was seven oz. heavier than that of the old man, æt. 91 years. In this case the atrophy of the brain appears to be connected with an old apoplectic cyst in the right corpus striatum, the relic of a former attack. The thalami were much shrunk, in the way I have described at the commencement of the paper. The softening in the right hemisphere had proceeded to a considerable extent, and occasioned the fatal attack : traces of old ramollissement are denoted by the holes observed in the brain, which were probably connected with the yellow deposit in the corpus striatum.

\section{$C A S E \quad I I I$.}

Phthisis Pulmonalis; Hypertrophy of the Cranium; Atrophy of the Brain.

Jane Hacket, æt. 41, admitted in the last stage of exhaustion from pulmonary tubercles. She had slight diarrhoea, which was easily checked; and was greatly emaciated. She had no head symptoms.

Inspection, forty=four hours after death, May 12. Head.-Cranium hypertrophied, in front especially, 
but also over the whole calvaria. Three oz. of fluid were found in the ventricles, and a very large quantity in the membranes, in some parts of a dusky colour. The vessels of the membranes were dilated, and those of the brain highly congested. The substance was soft from interstitial fluid, otherwise it was natural. Weight, 2 lbs. 14 oz.

Thorax.-Lungs: cavity at the upper part of right lung the size of an orange. The lungs extensively tuberculated, and containing many cavities. Heart small, atrophied.

Abdomen.-Stomach thinner than usual. No ulcerations in the intestines. Liver large, and going on to the granular form : slightly fat. Right kidney healthy.

Remarles.-The thoracic viscera were removed before the brain was dissected, but this had no effect in unloading the vessels of the brain.

The hypertrophy of the skull appears to be in the diploe. This case is introduced as an example of copious serous effusion into the membranes, ventricles, and substance of the brain, in a case of phthisis pulmonalis attended with great emaciation, the patient having had no head symptoms. The quantity of fluid, and the thickness of the cranium, must have encroached upon the cavity in a volume equal to from six to eight fluid-ounces; and the brain, otherwise 
healthy, must have diminished in bulk to the same amount.

$$
\text { CASE IV. }
$$

Pertussis; Pneumonia; Scrofulous Tumours in the Brain, Langs, Liver, \&c.; Atrophy of the Cerebellum.

Thomas M'Key, æt. one year and a half. This child was admitted with hooping-cough : pneumonia soon appeared, and the brain subsequently became embarrassed. He lingered several days without any marked increase of cerebral symptoms.

Inspection, May 21, seventeen hours after death. Head.-Blood-vessels of the membranes and substance of the brain loaded. Fluid between the membranes, and four oz. in ventricles. A scrofulous tubercle was found near the surface of left middle lobe, about the size of a filbert : another was found, about the same size, attached to the dura mater, a little above the tentorium, on the right side. The left lobe of the cerebellum appeared to be about its natural size, the right only one-third its ordinary size : in the occiput the depressions corresponded with the relative size of the lobes of the cerebellum. The tumours were cheeselike, of a lemon-yellow colour, and beginning to soften. Weight, 2 lbs. 4 oz.

Thorax.-Heart large for the age. Lungs: a tumour, similar to those in the head, the size of a 
walnut, at the upper part of the right lung; in other parts, ordinary pulmonary tubercles. Traces of lobular pneumonia, with whiteness from emphysema.

Abdomen.-Large tubercular masses, of the same colour and consistence, in the mesentery, and in other absorbents of the cavity. In the liver, numerous small tubercular masses.

Remarlss.-From the diminished cavity in the right side of the occipital bone, it is probable that the corresponding lobe of the cerebellum was originally deficient in size, or that it had ceased to grow in proportion to the other lobe, at an early period after birth.

In the model before the Society, which was taken from a patient of $\mathrm{Mr}$. Stafford who died from cancer of the face, \&c., absorption of the brain and flattening of the convolutions are well shewn. The orbits are almost entirely removed by absorption, and the dura mater is seen increased to three times its usual thickness, stretched across in a right line, and thus pressing upon the anterior lobes of the cerebrum. The pulsatory motion of the brain could be seen on looking into the deep ulcerated cavities of the face.

The following short notices of cases of atrophy of the brain will, I think, illustrate the subject.

I. A man, æt. 73, admitted in an emaciated 
and feeble state from diarrhœa and incontinence of urine : he lived three days. The brain contained a large quantity of fluid, and weighed 2 lbs. only.

II. A woman, æt. 71, admitted in a dying state : has been in a very destitute condition. On inspecting the brain, an old apoplectic cyst was found in the corpus striatum of the right side : arteries of the brain diseased; the ventricles large, and distended with fluid. Weight, 2 lbs. 5 oz.

III. A woman, æt. 79, died from pale ramollissement in the right middle lobe of the cerebrum. A large quantity of fluid was found in the membranes, and eight oz. in the ventricles. Weight, 2 lbs. 5 oz.

On the same day the brain of a child, three years old, who died of pneumonia, was examined; the vessels of the brain were highly loaded: there was some fluid. Weight, $2 \mathrm{lbs.} 5 \mathrm{oz}$., equal to that of the old woman of 79 years.

IV. A woman, æt. 78, died of extensive ramollissement of the posterior half of the right hemisphere. Weight, 2 lbs. 6 oz.

V. A woman, æt. 75, had an apoplectic attack seven years ago, and was carried off by a repetition of the disease. On examining the brain, traces of the old apoplexy and ramollissement were found. Brain weighed 2 lbs. 6 oz. 
On the same day, the body of a girl, æt. 12, who died of pneumonia, was examined. The brain was highly loaded, and contained some fluid. Weight, 2 lbs. 12 oz.; six oz. more than the brain of the woman æt. 75 .

VI. A man, æt. 62, whose case is detailed in a former paper, is an instance of atrophy attended with copious effusion into the ventricles and old cysts. Weight, 2 lbs. 6 oz.

VII. Also detailed in a former paper. A woman; æt. 67. Copious effusion between the membranes, and eight oz. in the ventricles, attended with an old cyst. The brain appeared fibrous, probably from absorption of the softer parts.

It occasionally happens, that on weighing a brain it is found to be equal to the average weight; but from the great quantity of fluid contained in the ventricles or membranes, atrophy to a great extent has taken place : the three following are cases of this description.

VIII. A man, æt. 46, had been in an imbecile state of mind for nine months : he died from erysipelas of the scalp. On examining the brain, a large quantity of fluid was found in the sub-arachnoid tissue : the ventricles contained eight oz. of fluid. The cerebral substance, extending upwards from the 
posterior cornu of the left ventricle, had almost entirely disappeared. Weight, 2 lbs. 15 oz.

IX. A girl, aged 6, a very delicate child, had suffered several attacks of hæmoptysis, and died of pulmonary tubercles. Cranium, deep blue. Membranes raised by fluid. A large quantity of fluid in the ventricles. Weight, 2 lbs. 7 oz.

X. A girl, æt. 6, lingered a long time with copious purulent expectoration from tubercles, and became much emaciated. In the brain there was a large quantity of fluid between the membranes and in the ventricles. Weight, 2 lbs. 6 oz.

XI. A man, æt. 60, with phthisis and hemiplegia : in the brain was found the remains of a clot of a rusty colour, in the anterior part of the right hemisphere. Weight, 2 lbs. 5 oz.

On the same day was examined the body of a boy, æt. 14, who died of phthisis : in the brain considerable effusion was found, and the weight was $2 \mathrm{lbs}$. 14 oz., nine oz. heavier than that of the man æet. 60.

\section{Inferences from the preceding facts and observations.}

1. From the short historical sketch it appears that pathological writers have hitherto had a very imper- 
fect knowledge of the phenomena connected with hypertrophy of the brain. M. Laennec did not observe the peculiar changes of structure which the brain presents in this affection. Scoutetten notices the greater consistence of the brain. Dance is the first to take much notice of the change of texture, though in his definition he limits the change to a mere addition of molecules. Portal, Otto, and Andral, have added several facts. British pathologists afford but faint indications of an acquaintance with the affection.

2. That cases of hypertrophy of the brain are met with where no change of texture can be discovered, and the enormous size of these brains arises from the mere addition of similar particles.

3. That cases of hypertrophy occur, in which, added to the increased size of the brain, there is a change in the texture of the brain, which has been described as resembling boiled albumen, ground-rice pudding, cream cheese, \&c. ; a flattening of the convolutions; little or no blood or serous fluid in the vessels, cavities, or membranes of the brain. That this state of the brain is of a more acute character, and is probably produced more or less rapidly by any causes that excite the brain or its blood-vessels, or that increase general or partial nutrition.

4. That hypertrophy is allied to or connected with apoplectic seizures, either as a precursor, a con- 
comitant, or a cause : that in this state of the brain, simple sanguineous apoplexy may be more readily induced, or life may be destroyed by a very small clot of extravasated blood.

I have no doubt that in the dissection of apoplectic brains, many cases of hypertrophy have been entirely overlooked, and the brain has been reported as normal; now, believing that I am correct on this point, I take the liberty of impressing on the minds of medical practitioners the further investigation of this subject, in consequence of its obvious bearing on the practical treatment of apoplexy and other diseases of the brain.

5. That extensive disorganization of the heart and lungs may impede the return of blood from the brain, or so obstruct its circulation as probably to occasion hypertrophy, or enlargement of the brain.

6. It is probable, that in cases of sudden death which on dissection have been attributed to a flaccid state of the heart, angina pectoris, spasm of the heart, \&c., hypertrophy of the brain, causing simple sanguineous apoplexy, though unnoticed, may have been the sole cause of death.

7. That in brains that are hypertrophied, both children and adults are sometimes destroyed by active inflammation of the brain, terminating in ramollissement; and also that this affection is frequently 
connected with the more slow form of ramollissement in adults, whether arising from inflammation or not.

8. That in some children who, from the size of the head, are suspected to be suffering under hydrocephalus internus, or the disease terminating in the deposition of fluid in the ventricles, it is highly probable that the brain is in a state of hypertrophy.

9. That the brain is sometimes affected partially by hypertrophy, either of one hemisphere, one lobe, or of the corpora striata or thalami.

10. That hypertrophy is confined to the cerebrum; the cerebellum is not so affected.

11. From an extensive series of observations, it appears that the average weight of the brain goes on increasing from 1 year old to 20 ; between 20 and 30 there is a slight decrease in the average: that afterwards it increases, and arrives at the maximum between 40 and 50 ; that after 50 to old age the brain gradually decreases in weight.

12. That the brain is sometimes unusually large, not amounting to hypertrophy, in persons dying of various diseases, especially in extensive pneumonia, and other diseases of the lungs and heart; and in these cases the brain is generally very much loaded with blood. 
13. That the brain in the advanced periods of life, and in some diseases, is diminished in volume or atrophied, either generally or partially; and that there are certain marks observed in dissection, by which this state of the brain may be known. It is also probable that there are symptoms occurring during life indicating atrophy of the brain.

14. That in phthisis pulmonalis, diseases of the stomach, and other emaciating disorders, the brain also sometimes undergoes a process of wasting.

15. That in cases of atrophy of the brain, the place previously occupied by cerebral substance is supplied by serous fluid, or by deposition of bone; and this deposit of bone frequently takes place on the inner surface of the cranium, sometimes in the diploe.

16. That the cerebellum is subject to atrophy, as well as the cerebrum. 